\title{
CHANGES IN SERUM ZINC LEVELS IN RELATION TO BLOOD PRESSURE DURING ANAESTHESIA
}

\author{
Garg H K ${ }^{1}$, Agrawal $\mathbf{P}^{2}$, Haleem $\mathbf{S}^{3}$
}

\section{ABSTRACT}

Fifty age and sex matched patients admitted for surgical operation, were divided into normotensive (control) and hypertensive (study) groups. Systolic and diastolic blood pressures were recorded preoperatively, $10 \mathrm{~min}$ after intubation, at max-increase of BP and 24 hours postoperatively. $5 \mathrm{ml}$. venous blood samples were drawn at these time periods, and serum zinc was also estimated. Control Gp (normotensive) subject recorded fall $(\mathrm{p}<0.001)$ in serum $\mathrm{Zn} 10 \mathrm{~min}$ after intubation $(\mathrm{n}=18)$ and $\max$. Rise of $B P(n=7)$, Twelve subjects in study $G p$ recorded a rise in serum $\mathrm{Zn}$ at max. Increase of BP (p < 0.01). The pattern in normotensives points towards mobilization of zinc, while in hypertensives, homeostatic, defence mechanisms appear to resist mobilization of serum $\mathrm{Zn}$ till maximum rise in BP occurs, indicating hormonal and other influences on serum $\mathrm{Zn}$ levels during anaesthesia.

Key Words: Serum Zinc, Systolic BP, Diastolic BP, Anaesthesia

\section{INTRODUCTION}

Zinc is a trace metal which may have a close association with blood pressure. Serum zinc levels are likely to get disturbed in hypertension. The present study was designed to explore the possibility of a relationship between serum zinc levels and changing BP during G.A.

\section{MATERIALS AND METHODS}

Fifty patients of similar age and either sex were entered into the study. These patients, who were to be operated for various ailments, were divided into two groups of 25 subjects each. The control group (Group I) included normotensive subjects while the study group (Group II) included hypertensive

1. Associate Professor, Department of Pharmacology, Nepalgunj Medical College, Chisapani (Banke)

2. Senior Resident, Department of Anaesthesiology, J.N. Medical College, A.M.U., Aligarh (U.P.), India.

3. Lecturer, Department of Anaesthesiology, J.N. Medical College, A.M.U., Aligarh (U.P.), India.

Address for correspondence : Dr. H. K. Garg, Associate Professor, Department of Pharmacology

Nepalgunj Medical College, Chisapani (Banke) Nepal.

Ph. No.: 081-29119, Fax: 081-21152 
subjects. Hypertensives were not operated till their BP came within normal range. Individuals with systemic or metabolic disorders or those receiving medications likely to affect serum zinc levels were excluded. Detailed history was taken and clinical examination and preoperative assessment was done in all cases. All patients were routinely investigated. Pulse rate and blood pressure were recorded in both upper limbs preoperatively, 10 minutes after intubation, at the maximum rise of $\mathrm{BP}$ and 24 hours after operation. BP was monitored every $10 \mathrm{~min}$ during operation, and the maximum increase ofBP was thus detected. $5 \mathrm{ml}$. venous blood samples were drawn simultaneously for the purpose of correlating BP and serum zinc levels. Preanaesthetic medication was given using diazepam and pentazocine $15 \mathrm{mg}$, i.v, slowly. Induction was done with a sleep dose of thiopentone sodium I.V. slowly. Relaxation was done with succinylcholine, $1.5 \mathrm{mg}$ / $\mathrm{kg}$ of body weight. The flow-in oxygen and nitrous oxide were-maintained in a ratio of 40:60. Maintenance of anesthesia was achieved with vancuronium bromide and reversal was carried out using, neostigmine, $0.05 \mathrm{mg} / \mathrm{kg}$ and inj. atropine, $0.02 \mathrm{mg} / \mathrm{kg}$ body weight in all patients. Blood samples were kept at room temperature till serum separated, which was then stored at $4^{\circ} \mathrm{C}$. Serum zinc was estimated by GBC 902 double beam, atomic absorption spectrophotometer. Statistical analysis of the data was done by Student's 'f test.

\section{RESULTS}

Mean systolic BP in the control group showed a rise ten minutes after intubation, $(p<0.001)$ No such change was seen in the study group. At maximum rise ofBP systolic BP increased in normotensives ( $p<0.001$, Table I), but no change was seen in the study group (Table II). In the postoperative period, however a different pattern

Table I

Serum Zinc Levels in Normotensive Patients During Anaesthesia (Data are mean \pm s.e.m., $n=25$ )

\begin{tabular}{|l|c|c|c|c|}
\hline \multicolumn{1}{|c|}{ Samples } & $\begin{array}{c}\text { Serun Zn } \\
\text { (ug/lOOm!) }\end{array}$ & $\begin{array}{c}\text { Pulse rate } \\
\text { (per min) }\end{array}$ & $\begin{array}{c}\text { Systolic BP } \\
\text { (mmHg) }\end{array}$ & $\begin{array}{c}\text { Diastolic BP } \\
\text { (mmHg) }\end{array}$ \\
\hline Pre-operative & $111.16 \pm 4.39$ & $91.84 \pm 2.71$ & $120.56 \pm 1.97$ & $80.16 \pm 1.55$ \\
10 min after intubation & $63.45 \pm 4.49 *$ & $98.16 \pm 2.31$ & $139.96 \pm 3.48^{*}$ & $93.20 \pm 2.13$ \\
At max. Increase of B P. & $78.44 \pm 5.25^{*}$ & $99.12 \pm 2.72$ & $150.88 \pm 3.10^{*}$ & $101.44+2.15$ \\
Post operative & $61.68 \pm 4.15^{*}$ & $85.44 \pm 1.92$ & $122.56 \pm 3.12$ & $84.40 \pm 2.67$ \\
\hline
\end{tabular}

$* P<0.001$, vs pre-operative

Table II

Serum Zinc Levels in Hypertensive Patients During Anaesthesia (Data are mean \pm s.e.m., $n=25$ )

\begin{tabular}{|l|c|c|c|c|}
\hline \multicolumn{1}{|c|}{ Samples } & $\begin{array}{c}\text { Serun Zn } \\
(\mathbf{U g} / \mathbf{1 0 0 m})\end{array}$ & $\begin{array}{c}\text { Pulse rate } \\
(\text { Per } \mathbf{m i n})\end{array}$ & $\begin{array}{c}\text { Systolic BP } \\
(\mathbf{m m H g})\end{array}$ & $\begin{array}{c}\text { Diastolic BP } \\
(\mathbf{m m H g})\end{array}$ \\
\hline Pre-operative & $135.16 \pm 5.10$ & $89.36+2.66$ & $154.32+2.33$ & $100.48 \pm 1.06$ \\
10 min after intubation & $112.46 \pm 4.54 * *$ & $98.5611 .20 * *$ & $147.36 \pm 3.00$ & $102.72 \pm 1.37$ \\
At max. Increase of B.P. & $139.30 \pm 7.72$ & $110.48+2.57 * * *$ & $161.20+2.54$ & $112.64+2.00 * * *$ \\
Post-operative & $117.00 \pm 9.81$ & $91.76+2.27$ & $141.76 \pm 4.26 *$ & $95.52+2.26$ \\
\hline
\end{tabular}

$* P<0.02, * * p<0.01$, ***p $<0.001$, vs pre-operative 
was observed. Systolic BP in the study group fell $(\mathrm{p}<0.02)$, while no change was observed in the control group.

Mean diastolic BP ten minutes after intubation showed a significant rise $(p<0.001)$ in the study group, while no change was observed in the control group (Table II).

Definite and distinct patterns of rise and fall in serum zinc levels were observed. Nonnotensive subjects were divided into two subgroups - I \& II, according to changes in serum zinc levels. a) Subgroup I: - Eighteen normotensives showed a fall in serum zinc $10 \mathrm{~min}$. after intubation, $(\mathrm{p}<0.001)$ which increased $(\mathrm{p}<0.001)$ at the time of peak rise of BP (Table III) . No change was recorded in the postoperative period.

b) Subgroup II: - Seven normotensives recorded a fall in serum $\mathrm{Zn}$ level at the time of peak rise of BP ( $\mathrm{p}<0.01)$. In the postoperative phase, the serum $\mathrm{Zn}$ level declined further $(\mathrm{p}<0.001$, Table III).

\section{Table III}

Fall in Serum Zinc Levels (ug/dl) in Normotensive Patients

(Data are mean \pm s.e.m.)

\begin{tabular}{|l|c|c|c|c|}
\hline \multicolumn{1}{|c|}{ Time of fall } & Pre-operative & $\begin{array}{c}\mathbf{1 0} \text { min } \\
\text { after intubation }\end{array}$ & $\begin{array}{c}\text { At max. } \\
\text { Increase of B.P. }\end{array}$ & $\begin{array}{c}\text { Post- } \\
\text { operative }\end{array}$ \\
\hline At 10 min. after intubation $(\mathrm{n}=10)$ & $108.30 \pm 6.92$ & $55.72 \pm 5.42 * * *$ & $68.93 \pm 4.51 * * *$ & $69.23 \pm 5.21 * * *$ \\
In post-operative phase $(\mathrm{n}=7)$ & $112.71 \pm 7.64$ & $84.28 \pm 7.63 *$ & $65.85 \pm 5.88^{*} *$ & $52.42 \pm 8.07 * * *$ \\
\hline
\end{tabular}

$$
* P<0.05, * * p<0.01, * * * p<0.001 \text {, vs pre-operative }
$$

On the basis of fluctuations in serum zinc levels, hypertensive subjects were divided into two subgroups:

a) Subgroup I: - Twelve hypertensive subjects showed a rise in serum $\mathrm{Zn}$ level at maximum rise of $B P(p<0.01)$. In the postoperative period, serum $\mathrm{Zn}$ fell (Table IV).

b) Subgroup II:- Thirteen hypertensives did not show any significant change in serum $\mathrm{Zn}$ throughout the study period (Table IV).

Table IV

Rise in Serum Zinc (ug/dl) in Hypertensive Patients

(Data are mean \pm s.e.m.)

\begin{tabular}{|l|c|c|c|c|}
\hline \multicolumn{1}{|c|}{ Time of rise } & Pre-operative & $\begin{array}{c}\mathbf{1 0} \text { min } \\
\text { after intubation }\end{array}$ & $\begin{array}{c}\text { At max. } \\
\text { Increase of B.P. }\end{array}$ & Post-operative \\
\hline $\begin{array}{l}\text { At max. After increase } \\
\text { of B.P. }(\mathrm{n}=12) \\
\text { No rise }(\mathrm{n}=13)\end{array}$ & $137.00 \pm 7.49$ & $111.9114 .62 *$ & $171.16 \pm 4.20 * *$ & $80.00 \pm 4.99 * * *$ \\
\hline
\end{tabular}




\section{DISCUSSION}

The importance of normal serum zinc levels in the body cannot be overemphasized, as zinc has been found to be essential for growth and development, as well as for the general well being of an individual. ${ }^{2}$ Zinc has been found to play an important role in the maintenance of blood pressure in rats. ${ }^{3}$ In the present study an attempt has been made to find out whether operative stress or general anaesthesia alter serum $\mathrm{Zn}$ levels. The serum zinc levels were significantly higher in hypertensive subjects as compared to normotensive subjects before anaesthesia.

The alteration in serum zinc levels during anaesthesia could be due to many factors. It could be due to the mobilization and redistribution of zinc. Redistribution of zinc was observed in hypertensives undergoing treatment with clopramide. Plasma, erythrocyte and W.B.C. levels of zinc registered an increase 8 weeks after initiation of therapy. ${ }^{4}$ Genetic predisposition to the effects of anaesthetic agents may be another reason of changes in zinc levels. Hypertension induced by deoxycorticosterone acetate was associated with higher serum zinc levels only in spontaneously hypertensive rats and not in normal rats. ${ }^{3}$ Yet another reason could be surgical stress. Surgical stress triggers the release of various mediators, possibly increasing hepatic zinc deposition, thus decreasing plasma and skin zinc levels. ${ }^{5}$ Studies on diverse tissue trauma such as following coronary bypass surgery, myocardial infarction ${ }^{7,8}$ and during fatigue $^{9}$ have shown that there is a significant decrease in serum zinc levels.

In the present study, the changes observed in serum zinc levels were uniform and correlated with specific events, namely, stress of intubation, stress of increase in blood pressure or with postoperative stress. Patterns in normotensives and hypertensives were also different. While a significant fall in zinc level at one time or the other was always observed in normotensives, serum zinc levels increased in hypertensive patients. Moreover, there are complex relations between zinc and arterial pressure, through the angiotensin converting enzyme (ACE) system and hormones like glucocorticoids and catecholamines used in the regulation of arterial pressure. ${ }^{9}$ Another factor, which may play a role in changes in serum zinc, is intraoperative hyperthermia. ${ }^{10}$

However, determination of zinc levels in hair and saliva also may help to give a clearer picture..$^{11,12}$

\section{CONCLUSION}

Serum zinc levels showed a fall in anaesthetized patient at the times of preoperative stress, due to intracellular mobilization. A rise in serum zinc was resisted by body homeostatic, defense mechanisms in hypertensive subjects, but serum zinc increased at the time of maximum rise in B.P., indicating ACE, and influences of other hormones. Serum zinc values are thus related to B.P. of anaesthetized subjects undergoing surgical stress.

\section{REFERENCES}

1. Ripa S, Ripa R. Zinc and arterial pressure. 1994; $85(9)$ : 455-9.

2. Prasad AS. Clinical, biochemical and phamacological role of zinc. Ann Rev Phamacol Toxicol.1974; 20: 393-426.

3. Fenrotte JG, santarromana M, Franck G, et al. High cardiac zinc levels in spontaneously hypertensive rats. J. Hypertens 1992; 10 (6) : 553-9

4 Du Preeez MJ. Lockett CJ. Effect of clopramide, a thiazide diuretic, on copper and zinc levels in hypertensive patients. J Am Coil Nutr. 1991; 10 (1) : 34-7 
5. Okada A, Takagi Y, Nezu R, et al. Zinc in clinical surgery - a research review. Jpn J Surg. 1990; $20(6): 635-44$

6. Antila HM, Salo MS, Kirvela 0, et al. Serum trace element concentrations and iron metabolism in allogeneric bone narrow transplant recipient. Ann Med 1992; 24 (1) : 55-9.

7. Katayama T, Honda Y, Yamasaki H, et al. Serum zinc concentration in acute myocardial infarotion. Angiology 1990; 41 (6) : 479-85.

8. Jain VK, Mohan G. Serum zinc and copper in myocardial infarction with particular reference to prognosis. Biol Trace Elem. Res. 1991; 31 (3) : 317-22
10. Taggarc DP, Fraser WD, Shenkin A, et al. The effects of intraoperative hypothermia and cardiopulmonary bypass on trace metals and their protein binding ratios. Eur J cardiothorac Surg. 1990; 4 (11) : 587-94.

11. Evens GW. Zinc absorption and transport. In AS prasad (Ed). Trace elements inhuman health and biseases vol. 1. Academic Press, NewYork. 1976; 181-7

12. Bales CW, Freeland Graves JH, Askey S, et al. Zinc magnesium, copper and protein concentrations in human saliva: age and sex related differences. Am JClinNutr. 1990; 51 : 462-9

9. Cordova Martinez A, Escanero Marcen JF. Changes in serum trace elements after surgery. Value of copper amd zinc in predicting postqperative fatigue. J. Int. Med. Res. 1992; 20 (1) : 12-9

\section{Notice for Fund Raising}

The Journal of Nepal Medical Association (JNMA) is consolidating all its efforts in upgrading the quality of the Journal that could subsequently lead to international recognition and indexing. The necessary changes in editorial policy have already come into effect and activities (e.g., peer reviewing, copy editing, statistical review etc) pertaining to it have been initiated. However, the Journal is currently short in funds to effectively conduct these activities. Hence, fund raising has become inevitable but as to how best funds could be raised and mobilized is still a question. Among those thought of are creating a revolving fund and/or acquiring a physical facility and renting them out so that the incurred interest and/or rent could be utilized to support the activities.

In this regard the Journal looks forward to the opinions of its valued readers. Comments and queries may be forwarded to the Chief Editor of Journal. 